\title{
VOZES DE PROFESSORES DA ESCOLA BÁSICA: EXPERIÊNCIA COM A INICIAÇÃO CIENTÍFICA DO ENSINO MÉDIO
}

\author{
VOICES OF SECONDARY SCHOOL TEACHERS: AN \\ EXPERIENCE WITH SCIENTIFIC INITIATION WITH HIGH \\ SCHOOL STUDENTS
}

Cristiane Carvalho de Paula Brito ${ }^{1}$

Marianna Ferreira Andrade ${ }^{2}$

Laura Pazini de Matos Siqueira ${ }^{3}$

Giovana Quites Machado Resende ${ }^{4}$

\begin{abstract}
Resumo: Este artigo contribui com reflexōes teóricas e práticas sobre letramento científico, no âmbito da Linguística Aplicada, a partir da investigaçāo dos resultados de um projeto de iniciaçấo científica desenvolvido por alunas do Ensino Médio, com objetivo de: (i) delinear algumas representaçôes de professores da educaçâo básica sobre si mesmos e sobre os processos de ensino-aprendizagem; (ii) investigar algumas vozes evocadas por esses sujeitos ao construírem essas representaçóes; e (iii) discutir possíveis implicaçôes das representaçôes para a prática docente. Com base no escopo teórico-metodológico da Análise do Discurso, de concepçóes bakhtinianas e dos estudos da Linguística Aplicada, apreendemos quatro vozes, nos dizeres dos participantes da pesquisa, a saber: a voz da vocaçăo, da satisfaçăo, da insatisfaçăo e da responsabilidade, as quais funcionam de forma a corroborar o imaginário de completude acerca da profissăo, abafando a percepçăo da falta.
\end{abstract}

Palavras-chave: Escola básica. Letramento científico. Representaçāo discursiva.

Abstract: This article contributes to the theoretical and practical reflections about scientific literacy, in the realm of Applied Linguistics, from the investigation of the results of a scientific initiation project developed by high school students, whose aims were to (i) delineate some representations built by secondary school teachers of themselves and the processes of teaching-learning; (ii) investigate some voices these subjects evoque when building such representations; and (iii) discuss possible

\footnotetext{
1 Doutora em Linguística Aplicada pela Universidade Estadual de Campinas. Docente na Universidade Federal de Uberlândia (UFU). depaulabrito@gmail.com

2 Bolsista PIBIC-EM/CNPq/FAPEMIG/UFU.mariannaferreira15@hotmail.com

3 Bolsista PIBIC-EM/CNPq/FAPEMIG/UFU. laura-pazini@hotmail.com

4 Bolsista PIBIC-EM/CNPq/FAPEMIG/UFU. giovanaquites@hotmail.com
} 
implications of the representations for teaching practice. Based on the theoretical and methodological scope of Discourse Analysis, of bakhtinian perspective of language and of the studies in Applied Linguistics, we identified four voices in the utterances of the participants. They are: the voice of vocation, of satisfaction, of insatisfaction and of responsibility, which corroborate the imaginary of completeness regarding the profession and obliterate the perception of lack.

Keywords: Secondary education. Scientific literacy. Discursive representation.

\section{INTRODUÇÃO}

O Programa Institucional de Bolsas de Iniciaçâo Científica Junior (PIBIC-JR FAPEMIG) e o Programa Institucional de Bolsas de Iniciaçăo Científica EnsinoMédio (PIBIC-EM CNPq)5 visam oportunizar a participaçâo de estudantes do Ensino Médio de escolas estaduais e municipais em atividades de pesquisa e divulgaçâo científica no âmbito da universidade. Após a aprovaçăo de um projeto submetido pelo professor da instituiçấo de ensino superior, a universidade entra em contato com as escolas sugeridas pelas Superintendências Regionais de Ensino para a seleçăo de alunos bolsistas para participarem da pesquisa, com duraçáo de 12 meses.

Para participar como bolsista, o aluno deve atender às seguintes exigências do programa: a) executar o plano de pesquisa aprovado pelo Comitê Científico do Programa; b) náo manter vínculo empregatício de qualquer natureza ou estágio remunerado; c) dedicar-se 12 horas semanais às atividades de seu plano de trabalho; d) apresentar os resultados alcançados sob a forma de pôsteres ou exposiçóes orais, por ocasiăo de evento ligado ao programa; dentre outras. Cumpre ressaltar que a seleçáo do bolsista é feita na própria escola, pela indicaçâo de professores, geralmente, com base no rendimento escolar e interesse do aluno. Compreendemos que a participaçăo de alunos da escola básica em iniciativas de pesquisa articuladas à universidade se configura como uma oportunidade singular de engajamento desses sujeitos em práticas de letramento científico, de forma a contribuir para o seu desenvolvimento acadêmico, além de ampliar a possibilidade de acesso ao ensino superior, gratuito e de qualidade.

Neste artigo, discutimos resultados do projeto intitulado Memória e discursividade em vozes de professores da escola básica, que foi desenvolvido de 2015 a 2016, em uma universidade federal no interior de Minas Gerais. O referido projeto foi orientado pela primeira autora e tinha por objetivo investigar representaçóes acerca do 'ser professor' e dos processos de ensino-aprendizagem, construídas por docentes da educaçâo básica de diferentes áreas do conhecimento.

Alguns trabalhos (BRITO, 2015; MELO; BRITO, 2014) sugerem que, ao enunciar sobre si e sobre sua profissăo, o professor tece seus dizeres a partir de imaginários de completude, os quais reforçam sentidos de idealismo e perfeiçăo que se confrontam com a percepçấo da falta (de valorizaçăo profissional e de preparaçâo, por exemplo). Tais sentidos, por sua vez, sâo produzidos sócio-historicamente e se filiam a redes

5 Os editais para os programas financiados pelo CNPq e pela FAPEMIG sâo lançados, respectivamente, no primeiro e segundo semestre de cada ano. 
ideológicas respaldadas por relaçóes de poder escamoteadas por discursos pedagógicos, midiáticos, institucionais, dentre outros.

Nas palavras de Santos (2011, p. 78-79):

A historicidade subjacente à forma-sujeito professor diz respeito a um código de normalizaçăo que o identifica numa especificidade de condiçóes, articuladas por sua inserçăo em uma diversidade de formaçóes discursivas. Esse código de normalizaçáo, por sua vez, traduz uma espécie de universalidade moral que institui o que é e o que deve ser dos atos vinculados ao caráter material dos sentidos de ser professor.

Desse modo, o referido projeto se justificou pela possibilidade de dar voz ao sujeito professor e estabelecer um gesto de escuta das memórias que o constituem enquanto profissional, oportunizando, ainda, o engajamento de alunos da educaçâo básica em investigaçôes de cunho científico que promovam a problematizaçăo de sentidos naturalizados e dados como evidentes, nas diversas práticas sociais de linguagem.

O letramento científico pode ser compreendido como práticas de leitura e escrita relacionadas ao ensino de ciências (CUNHA, 2017) 6 . Todavia, aqui utilizamos o termo em uma perspectiva mais ampla. Para Silva (2016, p. 14), o letramento científico diz respeito a "práticas investigativas informadas pela escrita em funçăo da produçâo de conhecimentos necessários ao desenvolvimento humano na complexidade que lhe é constitutiva em diferentes domínios sociais, a exemplo das práticas de formaçāo de professores".

Fazemos coro com as palavras do autor e reiteramos que essas práticas investigativas informadas pela escrita, e ensejadas pelo letramento científico, possibilitam novos posicionamentos discursivos aos sujeitos. Em outras palavras, entendemos que o letramento científico, ao trabalhar com um objeto de investigaçăo, demanda do sujeito o posicionar-se no lugar de analista, sendo interpelado a refletir sobre seu objeto, recortá-lo, delinear um percurso de análise e lançar gestos de interpretaçâo a partir de um escopo teórico-metodológico. Aliás, a mobilizaçăo desse escopo é já um gesto de análise, uma vez que deve passar pelo crivo do pesquisador, pela sua capacidade em interpretar teorias à luz de seu objeto de estudo. Cumpre ressaltar que o lugar de analista năo é tomado aqui pela perspectiva de uma distância, mas pelo viés da "proximidade crítica" (BOAVENTURA SANTOS, 2001, p. 4 apud MOITA LOPES, 2006, p. 101), em que se assume a natureza política, histórica, socioideológica do conhecimento e o fato de estarmos "diretamente imbricados" neste (MOITA LOPES, 2006, p. 100).

Ademais, a noçấo de proximidade crítica dialoga com a perspectiva de letramento ideológico (STREET, 1984), o qual postula a relaçâo entre os modos de uso da leitura e da escrita e as questôes identitárias e culturais, as práticas sociais, destacando, assim, a situacionalidade das práticas linguageiras na produçăo de significados e a impossibilidade de usos neutros da língua.

6 Cunha (2017) propôe o diálogo do ensino de ciências com o jornalismo para explorar a noçấo de letramento científico. $O$ autor defende o uso deste último termo (em detrimento do termo alfabetizaçáo científica) e de textos da área do jornalismo para as práticas de leitura e escrita nas aulas de língua e de ciências. 
No intuito de discutir a investigaçăo desenvolvida, organizamos este artigo em três principais seçōes. Primeiramente, faremos a contextualizaçāo teórico-metodológica da pesquisa. Em seguida, passamos à análise e discussăo dos resultados. Finalmente, teceremos algumas consideraçôes sobre a relevância de programas de cunho científico voltados para alunos do ensino médio.

\section{ESCOPO TEÓRICO-METODOLÓGICO}

O projeto em questăo fundamentou-se no escopo teórico-metodológico trans/ indisciplinar da Linguística Aplicada em sua interface com a Análise do Discurso de linha francesa em diálogo com concepçóes bakhtinianas de linguagem. Escopo esse que nos permite lançar olhares para a formaçăo de professores e para os processos de ensino-aprendizagem, por meio da mobilizaçăo de noçóes como as de sujeito, linguagem, discurso, sentido, dialogia e polifonia, dentre outras, sob um viés que refuta concepçôes dicotômicas e totalizantes (BRITO; GUILHERME, 2013).

Partimos da compreensâo de que năo há para o sujeito posiçăo de exterioridade em relaçăo à linguagem (AUTHIER-REVUZ, 2004) e de que é na e pela linguagem que se constituem as identidades, sempre moventes e fluidas. É na e pela linguagem que o professor se constitui como sujeito e que constrói, reproduz e mesmo resiste a discursividades que o circunscrevem a determinadas práticas sociais. Ademais, as 'minhas' palavras săo sempre permeadas por vozes outras, sendo o enunciado "pleno de ecos e ressonâncias de outros enunciados com os quais está ligado pela identidade da esfera da comunicaçăo discursiva" (BAKHTIN, 1953/2003, p. 297).

Durante o desenvolvimento desta pesquisa, foram debatidos textos teóricos ${ }^{7}$ que abordassem noçôes de linguagem, ideologia, sentido, historicidade, a partir de autores que de alguma forma tangenciassem os pressupostos teóricos dos estudos de Pêcheux (1969/1997; 1975/1997; 1983/1999; 1983/2002), Orlandi (2004, 2005a, 2005b), Bakhtin (1953/2003, 1929/2008), Moita Lopes (2006), Bohn (2005), Pennycook (2006), dentre outros.

Tais textos permitiram-nos compreender a natureza heterogênea, equívoca e opaca da linguagem, o que implica na possibilidade de se trabalhar com o inevitável deslize e náo fechamento dos sentidos. Trata-se, pois, de entender a linguagem "como produçăo de sentidos na interaçăo social, portanto, năo fixa, mas móvel, năo homogênea, mas sempre marcada pela enunciaçăo e, portanto, afetada pelos traços culturais do entorno social em que se realiza" (BOHN, 2005, p. 19).

A partir dessa inscriçăo teórica, nosso interesse foi o de investigar as vozes mobilizadas e/ou silenciadas, nos dizeres de professores, ao enunciarem sobre si e sobre os processos de ensino-aprendizagem e problematizar as implicaçóes ideológicas que sustentam suas representaçôes, de forma a contribuir para a consolidaçâo da formaçâo política do profissional da educaçâo (LEFFA, 2001).

Dessa forma, foram propostos os seguintes objetivos para a pesquisa: (i) delinear as representaçôes de professores da educaçăo básica sobre si mesmos e sobre os

$7 \quad$ Alguns dos autores estudados foram Fiorin (1998), Stella (2013), Di Fanti (2003), Pires (2002). 
processos de ensino-aprendizagem; (ii) investigar as vozes evocadas por esses sujeitos ao construírem essas representaçōes; e (iii) discutir as possíveis implicaçôes das representaçōes para a prática docente. O conceito de representaçáo é aqui tomado a partir da noçăo de formaçóes imaginárias, conforme postulado por Pêcheux, isto é, como o jogo de representaçôes "que designam o lugar que A e B se atribuem cada um a si e ao outro, a imagem que eles se fazem de seu próprio lugar e do lugar do outro" (PÊCHEUX, 1969/1997, p. 82).

Partiu-se da hipótese de que, ao enunciar sobre si e sobre os processos de ensino-aprendizagem, o professor tece seus dizeres a partir de imaginários de completude sócio-historicamente construídos que reforçam sentidos de idealismo e perfeiçấo e se confrontam com a percepçăo da falta (de valorizaçăo profissional e de preparaçăo, por exemplo), marcando seu discurso de embates e contradiçôes.

Para alcançar os objetivos propostos, o trabalho se fundamentou em uma metodologia qualitativa, com caráter analítico-descritivo e interpretativista, a qual nos permite compreender como se constituem os movimentos de identificaçáo dos sujeitos, por meio do discurso.

Foi utilizada a proposta AREDA - Análise de Ressonâncias Discursivas em Depoimentos Abertos, conforme elaborada por Serrani-Infante (1998), que consiste na análise das regularidades enunciativas (as ressonâncias de sentidos dos dizeres), a fim delinear como os sujeitos, ao enunciarem, evocam vozes oriundas de diferentes regiôes discursivas, que se contradizem, se refutam e se complementam.

Foram coletados depoimentos de seis participantes produzidos mediante gravaçăo de respostas a perguntas abertas feitas pelas alunas bolsistas. Os depoimentos foram coletados pelas alunas em suas respectivas escolas, sendo que os participantes gravaram sozinhos as suas respostas e enviaram os arquivos de áudio para transcriçăo8. Cumpre salientar que, para fazer parte da pesquisa, o participante deveria ser professor da escola pública atuando no Ensino Fundamental ou Médio e aceitar assinar o termo de consentimento livre e esclarecido9.

O questionário, elaborado pelas pesquisadoras, consistiu de perguntas que abrissem espaço para que os participantes (no caso, os professores-colaboradores) se posicionassem acerca de sua formaçâo e de aspectos pertinentes a sua prática profissional, como se observa no Quadro 1:

8 Para transcriçâo dos depoimentos, utilizamos as convençôes elaboradas por Guilherme (2008), a partir de outros autores.

9 O projeto foi submetido ao Comitê de Ética, sendo os depoimentos coletados e analisados após a devida aprovaçāo. 
Quadro 1: Questionário elaborado pelas alunas bolsistas.

1. Que disciplina você leciona?

2. Fale um pouco sobre sua formaçăo.

3. Como é sua jornada de trabalho?

4. Por que você escolheu ser professor(a)?

5. Você está satisfeito(a) com sua profissăo? Comente.

6. Você pensa ou já pensou em mudar de profissăo?

7. Que dificuldades você encontra para exercer sua profissâo?

8. O que te motiva a exercer sua profissâo?

9. Você considera a educaçâo no Brasil de boa qualidade?

10. Qual foi a sua maior conquista em sua profissăo?

11. Como você vê a profissăo do professor no Brasil?

12. Em que você se baseia para planejar suas aulas?

13. Qual a sua ideia de 'bom professor'?

14. Como você avalia a participaçâo dos alunos em suas aulas?

15. Você procura ou procurou algum tipo de aperfeiçoamento profissional após a sua graduaçăo? Comente.

16.16) Você está satisfeito(a) com sua prática pedagógica? Gostaria de mudar alguma coisa? Comente.

Os professores-colaboradores que aceitaram dar seus depoimentos ministram aulas em diferentes escolas estaduais, em uma cidade do interior de Minas Gerais. Abaixo apresentamos o Quadro 2 com um breve perfil de cada profissional.

Quadro 2: Perfil dos professores-colaboradores

1. Carmen: leciona Educaçăo Física, graduou-se em 2002, trabalha no turno matutino e leciona 16 horas aulas semanais.

2. Sandra: leciona Física, fez graduaçăo e licenciatura plena e especializaçăo em ensino de ciências e matemática. Atualmente faz mestrado na área de ciências e matemática. Leciona, em geral, 32 aulas por semana.

3. Afonso: leciona Língua Portuguesa, graduou-se em Letras e é especialista em psicopedagogia. Leciona no período matutino e é vice-diretor no período da tarde.

4. Taís: leciona Espanhol, graduou-se e atualmente faz mestrado. Tem um cargo de 16 aulas por semana, no estado, e também leciona em instituto particular de idiomas. 
5. Laura: leciona Língua Portuguesa e Literatura, graduada em Letras, tem especializaçăo na área. Leciona 32 horas. É professora há 30 anos.

6. Vanda: leciona Biologia, graduada em Ciências Biológicas, fez mestrado na área de saúde coletiva. Leciona 16 aulas por semana.

Na seçâo seguinte, passamos à descriçâo e discussâo dos resultados.

\section{VOZES DE PROFESSORES DA ESCOLA BÁSICA: DESTECENDO OS FIOS}

Conforme já dissemos, o corpus foi analisado com base na proposta AREDA (SERRANI-INFANTE, 1998) e balizado por uma perspectiva discursiva de linguagem. A profundidade analítica se adequou à proposta da pesquisa, a saber pelo fato de ser uma pesquisa de iniciaçâo científica desenvolvida por alunos do Ensino Médio.

Após leitura inicial das transcriçôes e discussóes em grupo, foram elencadas quatro vozes predominantes no corpus, que apontam o gesto de interpretaçáo das pesquisadoras, a forma pela qual os dizeres as interpelaram. Essas vozes se imbricam e aqui as separamos por questôes didáticas. Săo elas: (i) voz da vocaçăo; (ii) voz da satisfaçăo; (iii) voz da insatisfaçāo; (iv) voz da responsabilidade.

Pelas sequências apresentadas, observa-se que, ao evocar a voz da vocaçâo, o professor se representa como alguém apaixonado pela profissâo e como alguém que tem certeza do lugar que ocupa. Trata-se de uma voz que encontra eco no discurso messiânico, frequentemente evocado pelos profissionais que atuam na área do magistério, produzindo efeitos de que, antes de se exercer uma profissăo, exerce-se uma missáo, na qual se 'acredita muito' (SD10). Vejamos o Quadro 3: 
Quadro 3: a voz da vocaçăo

SD01: /... / No final da faculdade na verdade minha intençăo era me especializar em outras áreas da física, mas me apaixonei pelo magistério. (Sandra)

SD02: Se eu penso... Ou já pensei... Em mudar de profissâo... Nâo, nunca pensei... Nem cogitei essa possibilidade. (Sandra)

SD03: Escolhi ser professora... Porque eu acredito ainda na educaçâo. (Carmen) SD04: /.../ é acreditar que um dia a educaçâo vai ter seu verdadeiro reconhecimento e isso e o me motivo hoje a seguir em frente. (Carmen)

SD05: /.../ eu me apaixonei no magistério quando eu vi náo consegui sair mais. (Sandra)

SD06: /.../ é a paixáo mesmo, a vocaçâo pessoal. (Afonso)

SD07: /.../ eu gosto muito do idioma, me apaixonei e decidi ensinar a disciplina a quem quisesse (Taís)

SD08: Eu escolhi ser professor porque desde criança é eu sempre admirei meus professores pelo menos os melhores que eu já tive né eu via neles assim uma profissáo bonita de exercer /.../ (Afonso)

SD09: /.../ Gosto muito da língua espanhola /.../ me apaixonei e decidi ensinar a disciplina. (Taís)

SD10: /.../ porque eu fiz letras e acredito muito na profissâo (Laura)

SD11: /.../É realmente o que eu quero fazer para o resto da minha vida. (Vanda)

SD12: /.../ Eu sempre fui muuuito encantada assim com a... com os adolescentes sabe de conseguir mostrar que tudo pode ser mais interessante do que... do que eles realmente acham. (Vanda)

SD13: /.../ sempre continuando com a ideia de seguir como professora. (Vanda)

A voz da vocaçăo produz, assim, um efeito de encantamento e funciona de forma a abafar as incertezas e a criar um efeito de completude (a ponto de nem se cogitar uma mudança de profissáo - SD02; SD05; SD11; SD13). Todavia, vem à tona, no fio do dizer, a percepçấo da falta, marcada no uso do advérbio 'ainda' (SD03), na projeçâo de uma expectativa de melhora da área no futuro (SD04) e na idealizaçăo dos professores que se admiravam no passado (SD08).

Portanto, essa representaçâo funciona discursivamente de forma a abafar os conflitos e tensōes da profissāo, configurando-se como lugar de resistência para o sujeito frente aos inúmeros desafios e dificuldades que encontra como professor. Contudo, ao quase igualar a docência ao sacerdócio, a voz da vocaçâo pode contribuir para fragilizar a natureza política do ato de educar, impedindo que o professor se veja como sujeito sócio-historicamente situado e problematize as condiçôes materiais e ideológicas pelas quais se dá o seu fazer. Nấo se trata, pois, de negar a importância da afetividade, mas de compreendê-la a partir de uma noçáo náo ingênua, pautada na compreensâo de que os dizeres năo podem ser tomados em sua transparência, haja vista que a linguagem é 
opaca e os sentidos sâo produzidos sempre como efeitos, isto é, sempre na possibilidade do deslize.

Corroborando a voz da vocaçăo, a voz da satisfaçấo constrói a representaçáo de que o professor é aquele que se satisfaz no desenvolvimento (intelectual, cognitivo) e no sucesso (pessoal, profissional) do aluno. As realizaçôes desse outro legitimam e dâo sentido ao fazer docente (e diríamos à figura do professor em si), pois săo seu prêmio (SD15), a grande conquista (SD18) da profissăo, como se pode ver no Quadro 4.

Quadro 4: a voz da satisfaçāo

SD14: /.../ minha maior conquista foi fazer com que meus alunos se encantassem com a prática da Ed. Física que participasse ativamente das aulas e muitos até hoje me procuram interessados a trabalhar na mesma área e essa pra mim é a minha maior conquista. (Carmen)

SD15: /.../ ser professor nos traz benefício esse prêmio eu diria né a gente cresce muito se desenvolve muito como pessoa e como profissional isso me traz uma enorme satisfaçáo também. (Afonso)

SD16: Bom eu acredito que o que mais motiva um professor a dar aula sâo seus alunos /.../ maioria dos professores tem como maior motivaçâo os alunos mesmo /.../ quando você vê um aluno que no início náo sabia dizer nenhuma palavra e de repente ele sai conseguindo falar e escrever um texto acredito que isso é extremamente motivador. (Taís)

SD17: /.../ O que mais me motiva a exercer a profissăo... é pode fazer a diferença na vida de alguém e costumo a dizer que ... /.../10\% dos meus alunos tiveram ... um bom destino né eh e consegui fazer uma influência boa para eles eu já me considero vitoriosa. (Sandra)

SD18: /.../ acho que as conquistas acontecem todo ano quando a gente recebe aluno volta que vai à escola falar com a gente que fala ah aquilo que você me ensinou assim foi diferencial para o vestibular ou para um Enem ou até mesmo em uma faculdade quantos eu já náo encontrei que fazem alguma engenharia que falam que aquela física básica que eu ensinei foi o diferencial até outros que náo se referem a conteúdo propriamente dito a convivência comigo os toques que eu dei as dicas que eu dei terem sido positivas para a vida desses alunos isso é eh a grande conquista da minha profissáo (Sandra)

SD19: Conseguir ver todos ou quase todos os meus alunos na universidade. (Laura)

SD20: /.../ eu to feliz onde eu to (Vanda)

O desejo de fazer a diferença na vida de alguém (SD17) ressoa, de forma geral, nos dizeres por meio da celebraçăo das conquistas dos alunos, no fato de ver todos ou quase todos os meus alunos na universidade (SD19). Diferença essa que náo 
necessariamente advém do conteúdo de uma disciplina específica, mas sobretudo da convivência comigo os toques que eu dei as dicas que eu dei (SD18).

A voz da satisfaçăo, desse modo, também funciona de forma a apagar os conflitos que constituem a profissăo, ao projetar no outro um suposto desejo (pelo que o professor ensina, pela forma como ensina, pelo que representa) e uma (suposta) motivaçáo (SD16). A satisfaçăo, no depoimento dos professores, é na verdade oriunda de um deleite atribuído ao outro, haja vista que é esse outro que participa ativamente das aulas (SD14), que de repente sai conseguindo falar e escrever um texto (SD16), que teve um bom destino (SD17), que chegou à universidade (SD19).

A voz da insatisfaçấo, em embate com a voz da vocaçấo e da satisfaçăo, funciona de forma a representar a docência (e, portanto, o professor) como uma profissăo desvalorizada em termos financeiros, políticos e sociais, desenvolvida em meio a condiçōes precárias de trabalho. Nesse sentido, o professor ( $e$, consequentemente, o ensino) é representado como profissional totalmente desvalorizado na sociedade. 
Quadro 5: a voz da insatisfaçăo

SD21: /.../ a profissăo mais importante e a mais desvalorizada aquela que hoje está esquecida pelos governantes. (Carmen)

SD22: Eu náo considero que a educaçáo hoje no Brasil tenha boa qualidade acho que falta muito! Investimento na área tanto com matérias quanto na capacitaçáo dos professores da área hoje. (Carmen)

SD23: A minha jornada de trabalho é... ... É quase tortura! ... esse ano ... eu estou afastada de um dos meus cargos mais em geral eu tenho 32 aulas por semana fora todo o trabalho burocrático que a escola traz pra gente ... (Sandra)

SD24: A educaçăo no Brasil de boa qualidade? Nâo né! Nâo e boa qualidade năo ela é muito ruim muito ruim /.../ eu trabalho direitinho dentro das possibilidades mas o sistema nâo ajuda o aluno tá mal acostumado com a questăo do sistema empurrar náo estuda para aprender de verdade pouquíssimas sâo as exceçôes. (Sandra)

SD25: /.../ já quanto à jornada de trabalho e a questăo salarial e condiçóes de trabalho INFELIZMENTE nâo. (Afonso)

SD26: /.../ a jornada de trabalho bastante puxada chega a ser E-X-T-E-N-U-A-N-T-E. (Afonso)

SD27: /.../ Infelizmente nâo é uma profissăo muito valorizada nem em termos salariais nem em termos culturais muito menos políticos. (Afonso)

SD28: /.../ essa participaçăo dos alunos năo é apenas exclusivamente responsabilidade deles talvez se nós tivemos condiçōes melhores de trabalho trabalhássemos menos para planejar melhor nossas aulas tudo isso poderia contribuir na participaçâo mais efetiva dos alunos nas nossas aulas. (Afonso)

SD29: /.../ uma decepçâo ... porque o professor năo tem ess- é ... valorizaçâo necessária que ele deveria ter (Laura)

SD30: /.../ ter que esperar oito anos pra começar a receber por isso e ainda receber 140 reais a mais pra mim é um absurdo. (Taís)

SD31: /.../ profissâo do professor no Brasil eu vejo que ela é ... relegada a ... ao último patamar acho que nenhuma profissăo deveria ser mais importante que essa mas infelizmente no nosso país ... ela náo tem importância nem um pouco /.../ (Sandra)

SD32: Acho que todo mundo já pensou sim em mudar de profissâo. (Taís)

SD33: /.../ O professor entăo perde essa motivaçáo nâo tem salário bom náo tem uma infra-estrutura. (Taís)

SD34: Como eu disse eu acho muito mal remunerado muito desvalorizada /.../ a gente acaba levando trabalho para casa para corrigir essas coisas assim mas para mim que gosto muito do que eu faço năo... năo é um empecilho. (Vanda)

SD35: /.../ muitas horas de trabalho enquanto ganha muito pouco por isso. (Taís) 
As escolhas lexicais constroem um tom caótico para a profissâo (esquecida (SD21), tortura (SD23), muito ruim (SD24), extenuante (SD26), decepçáo (SD29), absurdo (SD30)) e denunciam a precariedade da educaçăo, ressoando dizeres já saturados na sociedade (haja vista a forma como sâo frequentemente promulgados pela mídia). A paixăo pelo magistério (como visto nas sequências 01 a 13) e a certeza de que se está na profissăo certa (SD02, SD05, SD11) parecem ser fragilizadas frente aos percalços e desafios impostos pelas condiçóes de trabalho, como se pode observar no dizer de Taís, por exemplo, (SD32: acho que todo mundo já pensou sim em mudar de profissâo), que, ao usar o pronome 'todo' e o advérbio 'sim', enuncia sobre o desejo de mudança de profissăo pela ordem da obviedade, produzindo o efeito de uma suposta verdade inquestionável.

A imagem de profissional desvalorizado se contrapóe a de um profissional que batalha e que se dedica, que trabalha direitinho (SD24), leva trabalho para casa para corrigir (SD34), tem muitas horas de trabalho (SD35), as quais chegam a ser extenuantes $^{10}(\mathrm{SD} 26)$, e que, por tais razóes, năo pode ser responsabilizado pela situaçăo da educaçăo no Brasil (SD22).

Desse modo, a voz da insatisfaçăo (d)enuncia os problemas de um sistema que náo ajuda (SD24), uma profissăo relegada ao último patamar (SD31), apontando, assim, o posicionamento político desses sujeitos. Entretanto, essa voz pode dar espaço para a inscriçăo no discurso do imobilismo, o qual enseja sentidos de impossibilidade e estagnaçăo, ressoando "vozes que estabilizam que năo há como mudar as mazelas da escola pública" (BRITO; GUILHERME, 2012, p. 168), daí a necessidade de ser problematizada.

Finalmente, a voz da responsabilidade traz à tona a representaçáo de bom professor. 0 emprego de vocábulos como conduzir (SD36), direcionar (SD38), passar o conteúdo (SD39), transmitir (SD40) e passar o seu conhecimento (SD42) constroem a imagem de professor como detentor de um saber a ser transmitido para o outro, trazendo à baila ecos de uma pedagogia tradicional. Portanto, o bom professor é (i) aquele que está preparado em termos de conhecimento; e (ii) aquele que prepara sua aula. O aluno, por outro lado, é representado como aquele que recebe o conhecimento.

10 Observe-se a ênfase dada ao professor ao referido adjetivo. 
Quadro 6: a voz da responsabilidade

SD36: O professor é aquele que... PENSA no ato de ensinar... de conduzir... o raciocínio e aaa construçáo de umaaa, de um senso crítico e de uma personalidade visando o futuro bem sucedido. (Laura)

SD37: /.../ queria ter mais tempo para preparar melhor minhas atividades que eu proponho na sala de aula /.../ (Sandra)

SD38: /.../ um bom professor é um professor que sabe fazer sua parte sabe explicar bem o conteúdo sabe direcionar o estudante para esse estudo autônomo ... que dá embasamento de conteúdo ... e que é coerente porque năo adianta o professor ensinar demais e năo avaliar bem o aluno ... năo sei ... acho que tem um série de coisas (Sandra)

SD39: /.../ tenta passar o conteúdo para aluno independente do que ele tenha que fazer se ele tem que explicar mil vezes, se ele tem que fazer um desenho se ele tem que esquematizar fazer um gráfico, independente da forma. (Vanda)

SD40: O bom professor ... E aquele que mesmo com todas as dificuldades que a gente encontra na profissáo consegue ainda transmitir com amor os conhecimentos e estimular os alunos no processo de aprendizagem. (Carmen)

SD41: É qual a minha ideia de bom professor o que é ser um bom professor deixa eu ver bom professor pra mim assim pensando rapidamente é aquele que consegue realizar seu trabalho e ver os resultados desse trabalho é ver esses resultados acho que isso acho que o bom professor é isso é aquele que consegue realizar seu trabalho e ver o resultado do seu trabalho. (Afonso)

SD42: Bom minha ideia de bom professor é um professor preparado um bom professor é aquele que está motivado que está ali porque quer estar ali náo por obrigaçáo que prepara sua aula que tenta sempre melhorar que tá sempre atrás de conhecimentos de coisas novas que prepara a aula como se tivesse preparando a aula para uma pessoa especial pra um filho năo pra qualquer um qualquer pessoa aquele que que realmente prepara algo útil pro aluno que realmente tenta passar o seu conhecimento pra ele isso é um bom professor pra ele eu acho. (Taís)

O sentido de preparaçăo é marcado pela projeçăo de uma imagem de perfeiçăo, em que se espera que o professor, independente do que ele tenha que fazer (SD39), mesmo com todas as dificuldades (SD40), seja capaz de ensinar, de desenvolver o senso crítico e uma personalidade visando o futuro bem sucedido (SD36). Enfim, trata-se de um profissional motivado (SD42), que năo está ali só por obrigaçāo e que tenta sempre melhorar (SD42), fazendo seu trabalho com amor (SD40).

A voz da responsabilidade, respaldada pela ilusăo de controle (do processo, do conteúdo, da compreensâo do aluno etc) evoca, assim, sentidos que apagam as condiçóes 
em que se dăo o ensino e a própria interaçăo professor-aluno, ao conferir ao professor o (suposto) poder de tudo controlar.

\section{CONSIDERAÇÕES FINAIS}

A identificaçâo das vozes nos depoimentos dos professores aponta para 'sentidos da docência'. Isto é, apesar de ressignificadas pela singularidade dos sujeitos, as vozes que emergem dos depoimentos ressoam dizeres que os precedem, frutos de uma memória discursiva que determina os sentidos (im)possíveis de serem enunciados, a partir do lugar que esse professor ocupa. Daí afirmarmos que analisar as vozes que tecem os dizeres de professores quando enunciam sobre a profissăo nos permite problematizar os discursos sócio-histórico-ideológicos que constituem esses sujeitos.

As vozes (da vocaçâo, satisfaçâo, insatisfaçâo e responsabilidade) identificadas a partir de nosso gesto de interpretaçăo corroboraram a hipótese elencada neste estudo: a de que, ao enunciar sobre si e sobre os processos de ensino-aprendizagem, o professor tece seus dizeres a partir de imaginários de completude sócio-historicamente construídos que reforçam sentidos de idealismo e perfeiçăo e se confrontam com a percepçăo da falta, marcando seu discurso de embates e contradiçóes.

Pela perspectiva teórica aqui adotada, entendemos que esses embates e contradiçóes podem ser problematizados (nos cursos de formaçâo de professores, por exemplo) a fim de explicitar as condiçôes (materiais, sociais, ideológicas) pelas quais a própria profissâo de professor é concebida no contexto da educaçâo brasileira. Dito de outro modo, năo se trata de tentar resolver os conflitos, uma vez que săo constitutivos dos sujeitos, mas de lançar olhares que permitam deslocamentos e transformaçôes, possibilidades aos sujeitos de (se)dizerem de outras formas, ocupando outras posiçóes discursivas, as quais incidem em suas práticas pedagógicas.

Em relaçăo à relevância de programas de iniciaçăo científica para o Ensino Médio, acreditamos que, ao promoverem a inserçăo acadêmico-científica desses alunos, tais programas abrem possibilidade para o desenvolvimento da autonomia e da responsabilidade. E, mais do que isso, considerando a experiência com a pesquisa aqui discutida, entendemos que a iniciaçăo científica - constituindo-se como importante prática de letramento científico - pode possibilitar deslocamentos subjetivos e identitários, ao permitir que esses sujeitos, ao contemplar a heterogeneidade, a contradiçâo, a nâo transparência da linguagem, se vejam de outra forma, pelo/no olhar do outro, já que "todo conhecimento em ciências sociais e humanas é uma forma de conhecer a nós mesmos e de criar possibilidades para compreender a vida social e outras alternativas sociais" (MOITA LOPES, 2006, p. 104). Ao serem interpelados a lançar gestos de interpretaçấo a um corpus, esses sujeitos, na posiçâo de pesquisadores, assumem um lugar de autoria, a qual é sempre construída em processos de alteridade, o que, por sua vez, pode trazer contribuiçōes para o percurso acadêmico-profissional desses alunos.

Para o professor orientador, tais programas abrem espaço para o diálogo com a sociedade e para o desenvolvimento de pesquisas responsivas à vida social e que buscam dar voz aos que comumente se encontram à margem das práticas e formas (legitimadas) de se construir o conhecimento. Tal compreensăo faz eco a uma noçâo contemporânea de Linguística Aplicada, cujos pilares sâo a ética e o poder, haja vista que a produçâo de 
conhecimento é sempre de caráter político (MOITA LOPES, 2006, p. 103). Nas palavras de Moita Lopes (2006, p. 103-104), "esse princípio ético é parte da constituiçăo de uma coligaçăo anti-hegemônica que colabora na construçâo de significados oriundos de outras vozes (daqueles marcados pelo sofrimento às margens da sociedade), assim como na construçâo de outro mundo social".

Em termos gerais, podemos dizer que um desafio no desenvolvimento do letramento científico, inclusive para aqueles que se dăo em contexto de (pós-)graduaçăo, reside no desenvolvimento de uma escrita acadêmico-científica que, extrapolando a mera aquisiçâo de técnicas, seja capaz de aventar traços de autoria, o que compreendemos ser parte de um processo situado de inscriçăo em discursividades.

Além disso, é importante frisar que, apesar de a realizaçấo de pesquisas como a que apresentamos aqui ficar ainda muito restrita devido à pequena disponibilidade de bolsas, entendemos que propostas como essas podem ser implementadas pelo próprio professor da escola básica, por meio, por exemplo, de projetos interdisciplinares que encorajem a construçâo de conhecimentos e investigaçóes que abram espaço para a constituiçăo do aluno enquanto sujeito histórico, constituído por uma memória, capaz, portanto, de tomar posicionamento na/pela linguagem.

E, nesse sentido, afirmamos que a experiência de orientar alunos da educaçăo básica, com vistas a desenvolver o letramento científico desses sujeitos, ressignifica o nosso lugar como professora formadora em curso de licenciatura. A experiência de orientaçấo acena para a importância de discutir, com os professores em formaçấo, propostas de letramento científico a serem desenvolvidas em suas práticas pedagógicas, o que pode iniciar, por exemplo, nas disciplinas de estágio supervisionado. No cerne dessas propostas, entendemos que está o questionamento da própria noçấo de linguagem, já que o letramento científico se pauta pela compreensáo de que as práticas de uso da língua escrita sâo plurais (KLEIMAN, 2008) e que, portanto, toda produçáo de conhecimento coloca em cena aspectos sociais, culturais, históricos, identitários, políticos e ideológicos.

Finalizamos esta reflexâo com o depoimento das alunas bolsistas, permitindo ao leitor atribuir sentidos à forma pela qual as pesquisadoras ressignificaram a experiência de desenvolver esta investigaçâo:

Todo esse tempo que se passou durante minha Iniciaçăo Científica no curso de Letras da [nome da instituiçăo de ensino superior] foi repleta de ensinamentos e aprendizagens. Além dos encontros que tivemos, criamos a liberdade de expor nossas opiniôes, nossas inquietaçôes e dúvidas que nos perturbaram levando-nos a enxergar e a refletir a verdadeira realidade que vive os nossos professores. E é com grande honra e satisfaçáo que eu encerro essa etapa com a certeza de que adquiri grandes amizades e uma enorme experiência. Muito obrigada, principalmente, à professora que me auxiliou e proporcionou grandes conhecimentos que espero usálos no decorrer do meu futuro. (Marianna Ferreira Andrade)

Eu gostei bastante de poder conhecer e fazer parte desse projeto, saber um pouquinho do que os professores pensam de si mesmo e dos seus trabalhos, foi muito importante para mim já que a minha escolha de curso superior também é 
ser professora e algumas coisas que eles falaram me influenciaram como pessoa, principalmente na voz da vocaçăo. Poder realizar um trabalho com uma professora da universidade e participar da construçâo de um projeto de pesquisa me ajudou muito a entender como săo feitas algumas pesquisas na mesma. No geral foi muito gratificante, foi uma experiência única, e vou levar tudo que fiz e aprendi com uma grande caminhada de aprendizado. (Laura Pazini de Matos Siqueira)

O projeto teve uma contribuiçăo incrível nâo só para meu crescimento pessoal como também acadêmico. Desenvolver uma pesquisa dentro da universidade que eu pretendo ingressar é uma forma de conhecer e querer ainda mais estar ali dentro. Além de ter adquirido conhecimentos de como analisar um texto e suas determinadas vozes, estar sempre com acompanhamento de uma profissional excelente me ajudou bastante a entender o propósito da pesquisa (Giovana Quites Machado Resende). 


\section{REFERÊNCIAS}

AUTHIER-REVUZ, J. Heterogeneidade mostrada e heterogeneidade constitutiva: elementos para uma abordagem do outro no discurso. Traduçāo Alda Scher; Elsa M. N. Ortiz. In: Entre a transparência e a opacidade: um estudo enunciativo do sentido. Porto Alegre: EDIPUCRS, 2004. p. 11-80.

BAKHTIN, M. Estética da criaçâo verbal. Traduçâo Paulo Bezerra. Săo Paulo: Martins Fontes, 2003.

BAKHTIN, M. Problemas da poética de Dostoiévski. Traduçâo Paulo Bezerra. 3. ed. Rio de Janeiro: Forense Universitária, 2008.

BOHN, H. Linguística Aplicada e Contemporaneidade. In: FREIRE, M.; ABRAHÂO, M. H. V. e BARCELOS, A. M. F. (Orgs.). Linguística Aplicada e Contemporaneidade. Campinas: Pontes, 2005. p. 11-23.

BRITO, C. C. P. Ser professor... Vozes de professores de línguas em formaçăo inicial. In: SANTOS, J. B. C.; GUILHERME, M F. F. (Orgs.). Estudos polifônicos em língua, literatura e ensino: laboratório de estudos polifônicos (Linguística in focus, v. 11). Edufu: Uberlândia, 2015. p. 213-230.

BRITO, C. C. P.; GUILHERME, M. F. F. Ensino de culturas estrangeiras em escolas brasileiras: um olhar sobre o discurso da mídia. Linguagem \& Ensino, Pelotas, v. 15, n.1, p.159-180, jan./jun. 2012.

BRITO, C. C. P.; GUILHERME, M. F. F. Linguística Aplicada e Análise do Discurso: possíveis entrelaçamentos para a constituiçâo de uma epistemologia. Cadernos Discursivos, v.1, n.1, p.17-40. 2013.

CUNHA, R. B. Alfabetizaçăo científica ou letramento científico?: interesses envolvidos nas interpretaçôes da noçâo de scientific literacy. Revista Brasileira de Educaçâo, v. 22, n. 68, p. 169-186. 2017.

DI FANTI, M. G. C. A linguagem em Bakhtin: pontos e pespontos. Revista de Estudos Linguísticos Veredas, v.7, n. 1 e n. 2, p. 95-111, jan./dez. 2003.

FIORIN, J. L. Linguagem e Ideologia. 6. ed. Sáo Paulo: Ática, 1998.

GUILHERME, M. F. F. (2008). Competência oral-enunciativa em língua estrangeira (inglês): fronteiras e limites. Tese de Doutorado. Programa de Pós-Graduaçâo em Linguística Aplicada e Estudos da Linguagem (LAEL), PUC-SP. 2008.

KLEIMAN, A. B. Os estudos de letramento e a formaçáo do professor de língua materna. Linguagem em (Dis)curso, v. 8, n. 3, p. 487-517, 2008.

LEFFA, V. J. Aspectos políticos da formaçăo do professor de línguas estrangeiras. In: LEFFA, Vilson J. (Org.). O professor de línguas estrangeiras; construindo a profissáo. Pelotas: Educat, 2001. p. 333-355.

MELO, L. C.; BRITO, C. C. P. Literatura (d)e (des)motivaçăo: representaçôes sobre o "bom professor" em relatórios de estágio supervisionado. Linguagem em (Dis)curso - LemD, v. 14, n. 2, p. 355-375. 2014.

MOITA LOPES, L. P. Linguística Aplicada e vida contemporânea: problematizaçăo dos construtos que tem orientado a pesquisa. In: MOITA LOPES, L. P. (Org.) Por uma lingüística aplicada indisciplinar. Săo Paulo: Parábola Editorial, 2006. p. 85-107. 
ORLANDI, E. P. Interpretaçâo: autoria, leitura e efeitos do trabalho simbólico. 4. ed. Campinas: Pontes, 2004.

ORLANDI, E. P. Discurso e texto: formulaçăo e circulaçăo dos sentidos. Campinas: Pontes, 2005a.

ORLANDI, E. P. A Análise de Discurso em suas diferentes tradiçōes intelectuais: o Brasil. In: INDURSKY, F.; Ferreira, M.C.L. (Orgs.). Michel Pêcheux e a análise do discurso: uma relaçâo de nunca acabar. Sáo Carlos: Claraluz, 2005b. p. 75-88.

PÊCHEUX, M. O Discurso: Estrutura ou Acontecimento. 3. ed. Traduçāo Eni Puccinelli Orlandi. Campinas: Pontes, 2002.

PECCHEUX, M. Papel da Memória. In: ACHARD, P. et al. (Orgs.). Papel da Memória. Tradução José Horta Nunes. Campinas: Pontes, 1999. p. 49-57.

PÊCHEUX, M. Análise Automática do Discurso (AAD-69). In: GADET. F.; HAK, T. (Orgs.). Por uma Análise Automática do Discurso: uma introduçăo à obra de Michel Pêcheux. Traduçăo Eni Orlandi. Campinas: Unicamp, 1997. p 61-151.

PÊCHEUX, M. Semântica e Discurso: uma crítica à afirmaçăo do óbvio. Traduçăo Eni Puccinelli Orlandi et al. Campinas: Editora da UNICAMP, 1997.

PENNYCOOK, A. Uma linguística aplicada transgressiva. In: MOITA LOPES, L. P. (Org.) Por uma linguística aplicada indisciplinar. Sáo Paulo: Parábola, 2006. p. 67-84.

PIRES, V. L. Dialogismo e alteridade ou a teoria da enunciaçâo em Bakhtin. Organon, v. 16, n. 32-33, p. 35-48. 2002.

SANTOS, J. B. C. Forma-sujeito professor \& lugar discursivo formador. In: SZUNDY, P. T. C. et al (Orgs.) Linguística aplicada e sociedade: ensino e aprendizagem de línguas no contexto brasileiro. Campinas, SP: Pontes Editores, 2011. p. 77-93.

SERRANI-INFANTE, S. Abordagem transdisciplinar da enunciaçâo em segunda língua. In: SIGNORINI, Inês; CAVALCANTI, Marilda. (Org.). Linguística aplicada e transdisciplinaridade. Campinas, SP: Mercado de Letras, 1998. p. 143-167.

SILVA, W. R. Letramento científico na formaçăo inicial do professor. Revista Práticas de Linguagem, v. 6 especial - Escrita discente, p. 8-23. 2016.

STELLA, P. R. Palavra. In: BRAIT, B. (Org.). Bakhtin: conceitos-chave. 5. ed. Sâo Paulo: Contexto, 2013. p. 177-190.

STREET, B. Literacy in theory and practice. Cambridge: Cambridge University Press, 1984.

\section{AGRADECIMENTOS}

Agradecemos à FAPEMIG e ao CNPq pelo apoio financeiro ao projeto. A investigaçấo aqui realizada contribui para as reflexóes que temos desenvolvido dentro dos grupos de pesquisa Práticas de Linguagens - PLES (UFT/CNPq) e Laboratório de Estudos Polifônicos (UFU/CNPq).

Recebido em novembro de 2017.

Aceite em março de 2018. 